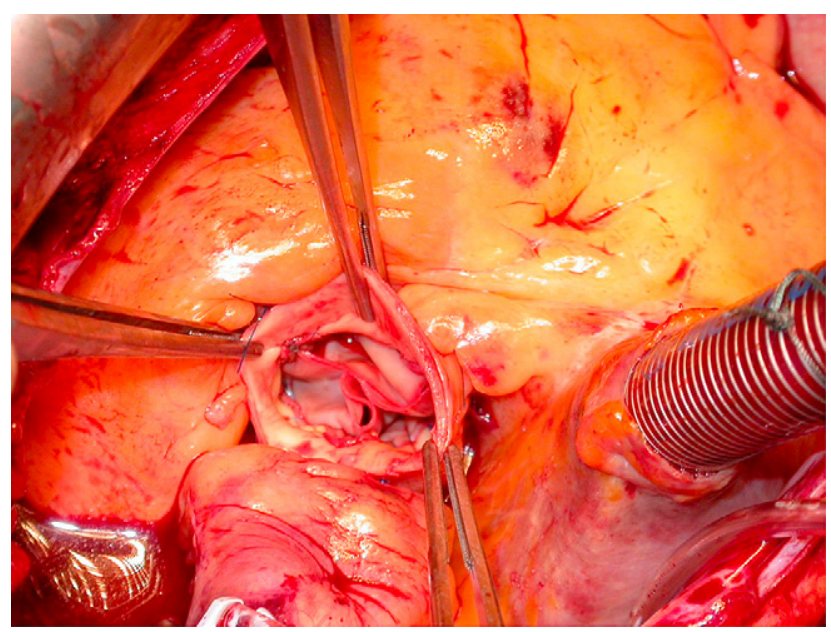

FIGURE 2. Intraoperative view with some excessive leaflet tissue assuming excellent coaptation.

patients. Postoperative hemodynamic performance was excellent (Table 1). Two (1.8\%) patients required permanent pacemaker implantation before discharge. Within a complete follow-up period extending up to 48 months, 2 patients underwent replacement of the valve because of regurgitation.

\section{DISCUSSION}

This is a prospective registry of the first 109 patients who received the new Sorin Freedom SOLO aortic tissue valve. Simpler technique of implantation was appreciated by all surgeons, and after a short learning curve it was found to be easier to implant than any other stentless valve.

One of the main goals of stentless valves is to improve hemodynamic performance. The elimination of the rigid ring allows some reduction in the transvalvular gradient and may lead to a more complete regression of the left ventricular mass and improved long-term survival. However randomized studies comparing stentless and stented valves show conflicting results. ${ }^{2-4}$

A substantial proportion of surgeons probably consider the implantation of a stentless valve more demanding than that of a stented valve, with longer perfusion and crossclamping times, and are reluctant to introduce stentless valves in their repertoire.

The new Sorin SOLO valve is considerably easier and faster to implant. The design is close to the structure of the native valve, and the strictly supra-annular implantation provides a greater effective orifice area index for a given valve size.

We confirmed the excellent hemodynamic performance ${ }^{5}$ and were able to implant larger sizes when compared with stented bioprostheses. The strictly supra-annular position seems to reduce the rate of postoperative complete atrioventricular block, which was only $1.8 \%$ in this series.

\section{References}

1. Ruel M, Chan V, Bédard P, Kulik A, Ressler L, Lam BK, et al. Very long-term survival implications of heart valve replacement with tissue versus mechanical prostheses in adults $<60$ years of age. Circulation. 2007;116(11 Suppl):I294-300.

2. Kunadian B, Vijayalakshmi K, Thornley AR, de Belder MA, Hunter S, Kendall S, et al. Meta-analysis of valve hemodynamics and left ventricular mass regression for stentless versus stented aortic valves. Ann Thorac Surg. 2007;84:73-8.

3. Ali A, Halstead JC, Cafferty F, Sharples L, Rose F, Coulden R, et al. Are stentless valves superior to modern stented valves? a prospective randomized trial. Circulation. 2006;114(1 Suppl):I535-40.

4. Perez de Arenaza D, Lees B, Flather M, Nugara F, Husebye T, Jasinski M, et al Randomized comparison of stentless versus stented valves for aortic stenosis: effects on left ventricular mass. Circulation. 2005;112:2696-702.

5. Da Col U, Di Bella I, Bardelli G, Ramoni E, Affronti A, Vidili A, et al. Short-term hemodynamic performance of the Sorin Freedom SOLO stentless valve. J Heart Valve Dis. 2007;16:546-50.

\title{
Intraoperative recognition of an intracavitary left anterior descending coronary artery
}

\author{
Lucas H. A. Sanders, MD, FCS(SA), FRACS, ${ }^{\mathrm{a}, \mathrm{b}}$ Mohamed A. Soliman Hamad, MD, ${ }^{\mathrm{a}}$ \\ Mark A. J. Newman, FRACS, MD, ${ }^{b}$ and Bart H. van Straten, MD, ${ }^{a}$ Eindhoven, The Netherlands, and Perth, \\ Australia
}

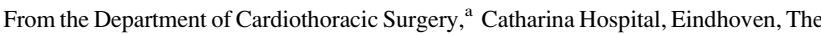
Netherlands; and Department of Cardiothoracic Surgery, ${ }^{\mathrm{b}}$ Sir Charles Gairdner Hospital, Nedlands, Perth, Australia.

Disclosures: None.

Received for publication Jan 28, 2009; accepted for publication Jan 31, 2009; available ahead of print April 9, 2009.

Address for reprints: Lucas H. A. Sanders, MD, FCS(SA), FRACS, Department of Cardiothoracic Surgery, Sir Charles Gairdner Hospital, Hospital Ave, Nedlands,

Australia (E-mail: lucmedi@hotmail.com).

J Thorac Cardiovasc Surg 2010;139:777-8

$0022-5223 / \$ 36.00$

Copyright (c) 2010 by The American Association for Thoracic Surgery

doi:10.1016/j.jtcvs.2009.01.016
}

An intracavitary left anterior descending (LAD) coronary artery, the extreme form of an intramyocardial coronary artery, is difficult to recognize, even on retrospective review of the coronary angiogram. ${ }^{1}$ The right ventricle usually is entered during explorative dissection. ${ }^{1}$ An intracavitary LAD typically enters the right ventricle early in its descending course (possibly with an acute angle) and emerges to the surface subtly in a long curve. With an acute change of depth course, one may suspect an intracavitary or intramyocardial location. ${ }^{1,2}$ Preoperatively, an intramyocardial coronary 


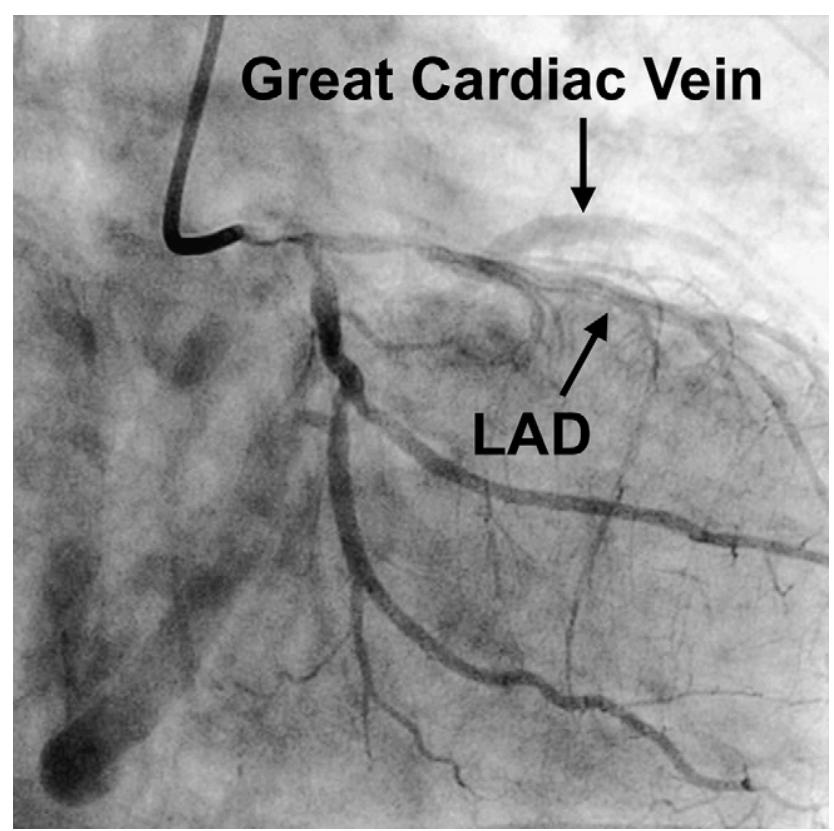

FIGURE 1. Significant separation between the LAD and great cardiac vein. $L A D$, left anterior descending coronary artery.

artery is suggested by a straight course and a systolic "milking effect" of myocardial fibers on the artery. ${ }^{1,2}$

We recently dealt with a right ventricular intracavitary LAD. We retrospectively recognized a significant separation between the LAD and the great cardiac vein, in the right anterior oblique view, at commencement of the venous phase of the selective left coronary angiogram (Figure 1). Although this entity will rarely be identified preoperatively, intraoperative review of the coronary angiogram can be of great value when the LAD is not found after superficial dissection. Recognition of an intracavitary LAD will prevent inadvertent entry into the right ventricle.

Familiarity with the coronary venous anatomy is important in identifying the non-obvious epicardial coronary arteries, especially with pericardial adhesions. ${ }^{3}$ On a coronary angiogram, depiction of the arterial and venous phase together is not common and depends on the amount and duration of contrast, radiation exposure, and coronary flow, among other factors. Even so, when depicted consecutively, mental superimposition of the arterial and venous phase can demonstrate the relation between the great cardiac vein and the LAD. Other methods to assist in intraoperatively locating an intramyocardial or intracavitary LAD are to trace back a distal or proximal LAD segment or branch, dissect on the right side of the great cardiac vein, palpate the (calcified) LAD, palpate an intraluminal probe inserted via a distal LAD or diagonal arteriotomy, or use a sterile epicardial Doppler ultrasound probe. ${ }^{1,2}$

Using a depiction of the great cardiac vein to recognize or suspect an intracavitary course of the LAD has not been reported before.

\section{References}

1. Ochsner JL, Mills NL. Surgical management of diseased intracavitary coronary arteries. Ann Thorac Surg. 1984;38:356-62.

2. Oz MC, Cooper MM, Hickey TJ, Rose EA. Exposure of the intramyocardial left anterior descending artery. Ann Thorac Surg. 1994;58:1194-5.

3. Cmolik BL, Geha AS. Coronary artery operations and reoperations, techniques and conduits. In: Baue AE, Geha AS, Hammond GL, Laks H, Naunheim KS, eds. Glenn's Thoracic and Cardiovascular Surgery. 6th ed. Stamford, CT: Appleton \& Lange; 1996:2081-92.

\title{
Management of aortobronchial fistula developing 27 years after open aortic surgery by means of endovascular stent grafting
}

\author{
Stefan Hacker, MD, ${ }^{\mathrm{a}}$ Herbert Langenberger, MD ${ }^{\mathrm{b}}$ Christina Plank, MD, ${ }^{\mathrm{b}}$ Michael Gorlitzer, MD, ${ }^{\mathrm{c}}$ \\ Marek Ehrlich, MD, ${ }^{\mathrm{a}}$ Werner Dolak, MD,${ }^{\mathrm{d}}$ Sören Kreuzer, MD, ${ }^{\mathrm{b}}$ Christian Loewe, MD, \\ Walter Klepetko, MD, ${ }^{\mathrm{a}}$ and Hendrik Jan Ankersmit, MD, ${ }^{\mathrm{a}}$ Vienna, Austria
}

\footnotetext{
From the Department of Surgery ${ }^{\mathrm{a}}$ and Radiology, ${ }^{\mathrm{b}}$ Medical University of Vienna, Vienna, Austria; Department of Cardiovascular Surgery, Hospital Hietzing, ${ }^{c}$ Vienna, Austria; and Department of Internal Medicine III, Medical University of Vienna, ${ }^{\mathrm{d}}$ Vienna, Austria.

Disclosures: None.

Received for publication Nov 26, 2008; accepted for publication Feb 20, 2009; available ahead of print April 27, 2009.

Address for reprints: Hendrik Jan Ankersmit, MD, Department of Cardiothoracic Surgery, Medical University of Vienna, Waehringer Guertel 18-20, 1090 Vienna, Austria (E-mail: hendrik.ankersmit@meduniwien.ac.at).

J Thorac Cardiovasc Surg 2010;139:778-80

$0022-5223 / \$ 36.00$

Copyright (c) 2010 by The American Association for Thoracic Surgery doi:10.1016/j.jtcvs.2009.02.036
}

Fistulous connections between the thoracic aorta and the bronchial systems are rare but potentially fatal complications. However, reports are limited and guidelines for diagnosis and treatment are not available. Most often, patients have a history of reconstructive vascular surgery followed by anastomotic aneurysm or dissection. Aortobronchial fistulas (ABFs) regularly present with mild to massive hemoptysis and chest pain. ${ }^{1}$ Given the high mortality of untreated patients, immediate patient management with either open surgery or endovascular repair is essential. We present the 